\title{
Embryonic diapause
}

\author{
Mesut ÇEVIK ${ }^{1}$, Merve Deniz GENÇ ${ }^{1}$
}

${ }^{1}$ Department of Reproduction and Artificial Insemination, Faculty of Veterinary Medicine, Ondokuz May1s University, Samsun/TURKEY

Key Words:
blastocyst
diapause
embryo
evolutionary strategy

\author{
Anahtar Kelimeler: \\ blastosist \\ diyapoz \\ embriyo \\ evrimsel strateji
}

$\begin{array}{ll}\text { Received } & : 03.12 .2020 \\ \text { Accepted } & : 06.02 .2021 \\ \text { Published Online : } 30.04 .2021\end{array}$

Article Code : 835288

Correspondence:

M. CEVIK

(cevikm@omu.edu.tr)

ORCID

M. ÇEVIKK : 0000-0002-0754-6116

MD. GENC : 0000-0002-7822-2100

\begin{abstract}
Embryonic diapause in other words temporary cessation of embryonic development is a common some plant and animal species. Embryonic diapause is a temporary cessation of the development of embryogenesis in the blastocyst stage and is a reproductive strategy characterized by delayed implantation in the uterus. It is defined in over 130 species of mammals. It occurs obligate or facultative in cases where the development of the embryo from the blastocyst stage to later stages is not appropriate (eg, during environmental conditions or lactation). The embryonic diapause begins with the blastocyst entering the metabolic and proliferative state of silence so reduction or interruption of mitosis in the embryo. When exit from the diapause, reactivation, blastocyst returns to active metabolism, mitotic activity restarts and with cell proliferation, the implantation process begins in the uterus. Embryonic diapause is a protective phenomenon, it represents an important developmental advantage for species survival and should be evolutionarily protected.
\end{abstract}

\section{Embriyonik diyapoz}

\section{ÖZ}

Embriyonik diyapoz veya embriyo gelişiminin geçici olarak durdurulması, bitki ve hayvan türlerinde yaygin bir fenomendir. Embriyonik diyapoz, embriyogenezisin blastosist aşamasında gelişiminin geçici olarak durdurulmasıdır ve uterusta gecikmeli implantasyon ile karakterize bir üreme stratejisidir. 130'dan fazla memeli türünde tanımlanmıştır. Embriyonun blastosist asmamasından daha ileriki aşamalara gelişiminin uygun olmadığı durumlarda (örneğin çevresel koşullar veya laktasyon döneminde) zorunlu olarak ya da fakültatif olarak meydana gelmektedir. Embriyonik diyapoz, blastosistin metabolik ve proliferatif sessizlik durumuna girmesiyle başlamaktadır yani embriyodaki mitozun azaltılması veya kesilmesidir. Diyapozdan çıkış $\square$, reaktivasyon, şekillendiğinde blastosist aktif metabolizmaya geri dönmektedir, mitotik aktivite yeniden başlamaktadır ve hücre proliferasyonu ile beraber uterusa implantasyon süreci başlamaktadır. Embriyonik diyapoz koruyucu bir olgudur, türlerin hayatta kalması için önemli bir gelişimsel avantajı temsil etmektedir ve evrimsel olarak sürdürülmelidir.

\section{INTRODUCTION}

The embryo develops on its own before implanting into the uterus. However, when it reaches the blastocyst stage, its metabolism inherently slows down and cannot develop further in the absence of appropriate stimuli in the uterus (16). Pregnancy can be blocked in the presence of an unfavorable environment such as uterine causes, metabolic, climatic conditions. Carnivore, Rodentia or Diprotodontia embryos who event hard climates, malnutrition, metabolic stress or breastfeeding, enter diapause (29). Embryonic diapause, also known as delayed implantation, is the arrest of blastocysts in the early stage of the embryo. So cell division, development and blastocyst expansion cease or are very considerably reduced and there is down-regulation of metabolism. It includes the uncoupling of mating and fertilization from birth. So it is an evolutionary strategy by ensuring that postnatal development occurs under the most favourable environmental conditions for the survival of the offspring. It is known to occur in more than 130 species (for example roe deer, polar bear, giant panda) in blastocyst stage (7). It can take from a few days to 11 months depending on the species. Although the property of diapause differ between species according to the endocrine status the purpose is; extending the gestational period, ensuring that the offspring are born at the propitious moment of the year according to the feeding, environmental conditions, and if the mother has given birth and breastfeeding before conception, she gives all her metabolic resources to her newborn babies (19). The striking thing about diapause is that early embryonic cells stop dividing, but this is reversible. To understand how this is controlled at the molecular level; it has the potential to aid in many situations, such as improving the viability of blastocysts in assisted reproductive technologies, deriving embryonic stem cells or slowing cell division and identifying new cancer therapies by halting cancer cells. In 
essence embryonic diapause is the study of how to stop and restart cell growth (8).

\section{The embryo in diapause}

The success of reproduction is depends on the external (photoperiod, season as) and internal (hormones as) the conditions. In the absence of conditions for successful reproduction, different adaptations may occur depending on the species. An example of these adaptation situations is delayed fertilization (31), delayed implantation or postimplantation delay (seen some in bats). All this adaptation status has to aim: the gestational period is extended so the birth of offspring when environmental conditions are better (2). Embryonic diapause is a period in early development during which an embryo remains temporarily suspended at the blastocyst stage (30). It was the first species in which embryonic diapause exists in the roe deer (8). One of the main properties of diapause is regardless of the mating time or the normal birth time and it is the cessation of development in a period of pregnancy and controlling the birth time according to the environmental or physiological conditions. Although embryonic diapause varies between species, it can vary from a few days to 11 months. For example, rodents embryo can last from 1 day to several weeks in diapause or the tammar embryo can remain in diapause for 11 months. According to studies, it has been determined that diapause occurs in more than 130 mammal species. During diapause, there is minimal or no cell division, reduced cell metabolism, cell development is put on hold and despite all these situations, when the conditions become suitable, the pregnancy continues without any problems. (30). Diapause has effects on cell division apart from its effects on cell metabolism. It causes the mitosis in the embryo to decrease or stop during cell division. Although it depends on the species, cell cycle arrest may occur in the G0, G1 or G2 phase. The resumption of mitotic activity also means the end of diapause (19). Diapause occurs when the early embryo is in the blastocyst stage, blastocyst development either stops completely or develops very slowly, and after blastocyst stage continuity of pregnancy requires contact with the uterus and uterine secretory activity, which are dependent on ovarian steroids, blastocyst development either stops completely or develops very slowly, and after blastocyst stage continuity of pregnancy requires contact with the uterus and uterine secretory activity, which are dependent on ovarian steroids (30). In carnivores during diapause, blastocysts are not complete metabolically inactive since their oxygen consumption is continuous, and they continue to synthesize RNA, DNA and protein, although they are at lower rates compared to active blastocysts (22). Many factors can induce diapause; season, food, temperature, photoperiod and breastfeeding like (30). So, embryonic diapause in animals is a result of physiological stress factors (photoperiod, lactation), and all physiological and psychological stress factors directly change uterine receptors through the hypothalamic-pituitarygonadal (HPG) axis and affect the hypothalamic-pituitaryadrenal axis (15). Diapause is divided into 2 types according to physiological conditions (facultative) and reproductive season (obligate) in animal species. (22).

\subsection{Facultative embryonic diapause}

Facultative embryonic diapause is best known in rodents and marsupials. Rodents are the most used species in facultative diapause studies. In this study after fertilization, ovariectomy operation and hormone application (progesterone) is performed (27), and it can also be finished with estradiol application (36). If mating occurs with oestrus in mice, zygotes are transported to the uterus by reaching the blastocyst stage on the 4th day (10). In the uterus, optimal progesterone levels must be maintained for embryonic development to continue (37). However, if mating occurs while the mouse is breastfeeding its offspring, progesterone will remain below optimal concentrations and embryonic diapause takes shape. Embryonic diapause in rodents can last from 1 day to several weeks, depending on the number of pups in the suckling litter (25). The amount of progesterone released from the corpus luteum under the effect of the prolactin hormone is not sufficient since the mother is still breastfeeding her offspring in postnatal oestrus. That is, a low amount of released progesterone induces embryonic diapause. The prolactin secretion can also be enhanced by melatonin in Marsupialia (2). (Figure 1).

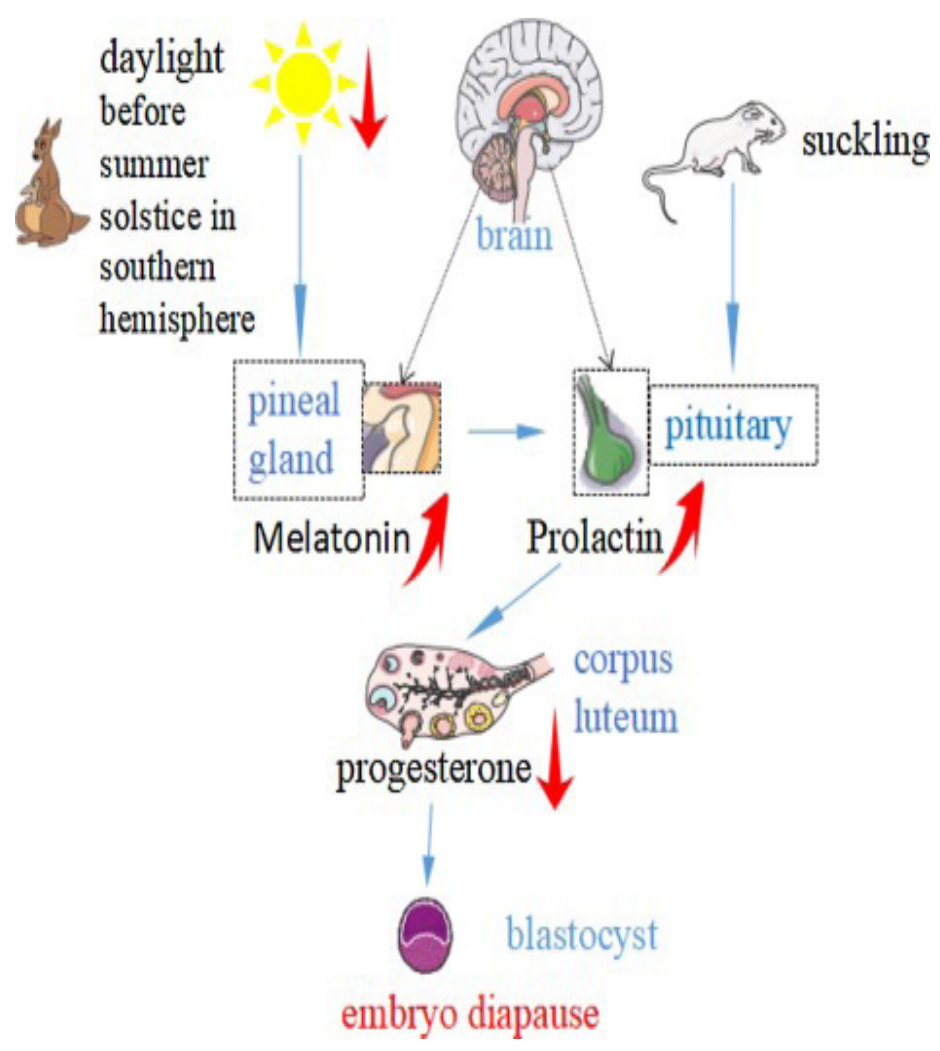

Figure 1. Regulation of facultative diapause (2). 


\subsection{Obligate (Seasonal) embryonic diapause}

In species in which obligate diapause occurs, the embryo undergoes diapause in during every reproductive season. When the environmental conditions are suitable for birth, the diapause ends and the pregnancy continues (33). Studies have shown that this process in mammals with obligate diapause is regulated by seasonal changes in the photoperiod (28). Mink, weasel, skunk has seasonal diapause, which also affects day length and melatonin levels in regulating diapause through prolactin. In skunks (Spilogale Gracilis) mating occurs in autumn and embryos remain in diapause for 200 days (21), likewise in minkes (Neovision Vison) they undergo a long or short diapause phase that can last about 2 weeks after mating in March (23). In carnivores, blastocysts continue to cluster in the uterus in diapause. The number and diversity of cells in embryos undergoing diapause is higher than in rodents. Embryos in obligate diapause are encapsulated in the zona pellucida of the oocyte (4). Minkes mate before the spring equinox when daylight is less than 12 hours. While this situation suppresses prolactin secretion, it causes an increase in melatonin secretion. At the same time, diapause begins, which will continue until after the spring equinox. The new studies show that polyamines as the factors that are required for reactivation of the embryo in diapause. Ornithine decarboxylase (ODC) is the rate-limiting enzyme for transformation of ornithine to putrescine. It can reactivate the development of mink embryos that are in the state of diapause (24) (Figure 2).

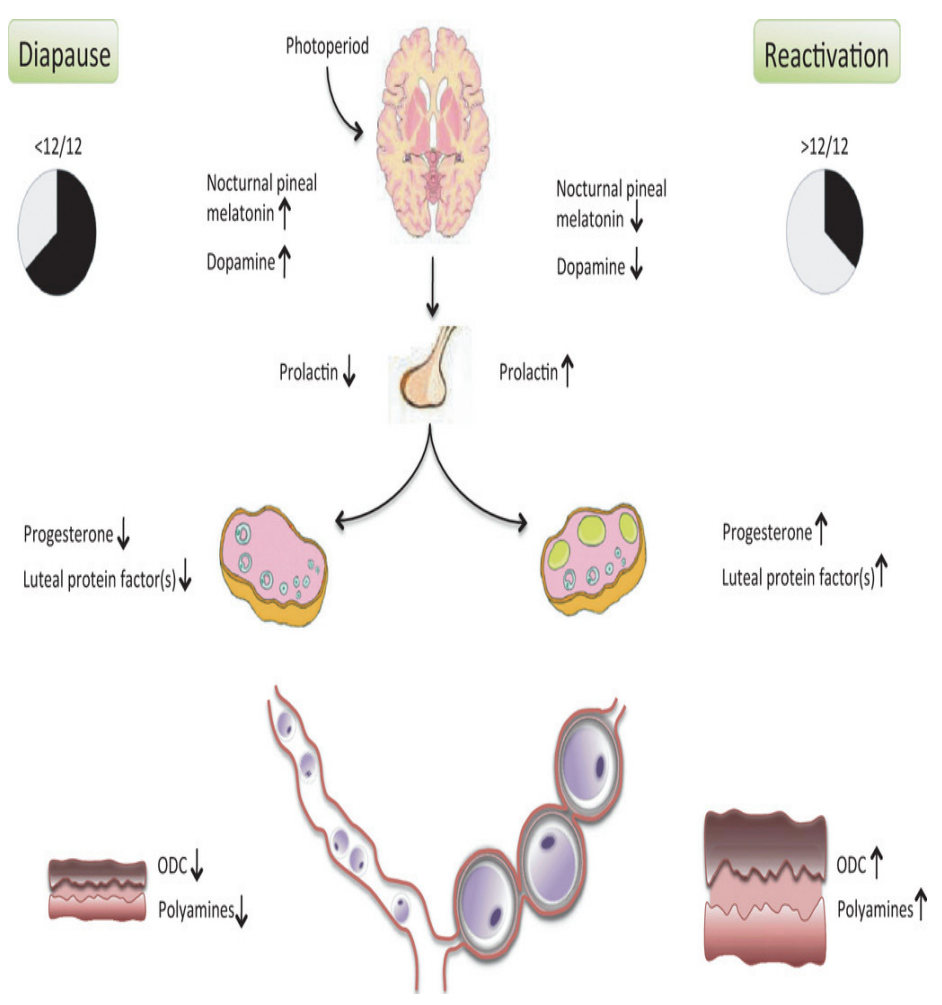

Figure 2. Endocrine and uterine regulation during diapause and reactivation in the mink (24).

\section{Hormones involved in diapause}

Prolactin, melatonin, progesterone, estrogen are important hormones in the initiation of diapause and reactivation. Prolactin hormone is secreted by the pituitary gland. Prolactin is an important hormone that has an effect on the initiation and continuation of breastfeeding in mammary gland development and the implantation of the embryo. It is also effective in the initiation of both obligate and facultative diapause. In obligate diapause photoperiod influences embryonic diapause and following reinitiating of embryo development by regulating the secretion of pituitary prolactin (5). In facultative diapause, fluctuations in prolactin concentration cause suppression of secretion from the corpus luteum and development. In facultative diapause, fluctuations in prolactin concentration cause suppression of secretion from the corpus luteum and development. Melatonin hormone is produced in the pineal gland and its biosynthesis is controlled by the photoperiod. Melatonin hormone is also effective in regulating embryonic development. Estrogen hormone optimizes embryonic implantation time, affecting both uterine and blastocyst activation, especially in mice. Estradiol-17B is used to start implantation in laboratory mice. Progesterone is a necessary hormone for both the regulation of diapause and implantation. The hormonal mechanism required for initiation, maintenance, and termination of diapause is complex and many molecules are required (2). To sum up the hormonal control of diapause depends on prolactin, estrogen and progesterone levels (29) (Figure 3).

\section{Molecular control of diapause}

Mouse, mink and tammar wallaby are the species in which the molecular part of diapause is best understood according to studies. and mink blastocysts are surrounded by multiple acellular layers and do not implant until a few days before reactivation, suggesting that the factors controlling diapause must reach the embryo via uterine secretions (28). It is thought that the mechanism that provides communication between the endometrium with blastocyst may be uterine secretions. Recent studies have revealed that a large number of proteins, hormones, cytokines, transcription factors are important in regulating embryonic development and are also effective in entering into diapause and reactivation. It has been shown that amino acids found in uterine fluids affect embryo development, but it has not been determined what the amino acids specifically affect (35). The uterine endometrium secretes cytokines and growth factors that affect the development of the preimplantation embryo. Some of these are known to control the arrested growth that occurs in diapause. Among these factors, Leukaemia Inhibitory Factor (LIF), InsulinLike Growth Factor (IGF), Epidermal Growth Factor (EGF), Fibroblast Growth Factor (FGF), Transforming Growth Factor-b (TGF-b) $(11 ; 14)$, PAF (formerly platelet activating factor), Vascular Endothelial Growth Factor (VEGF). However, molecular control of diapause is still not fully resolved (30). 


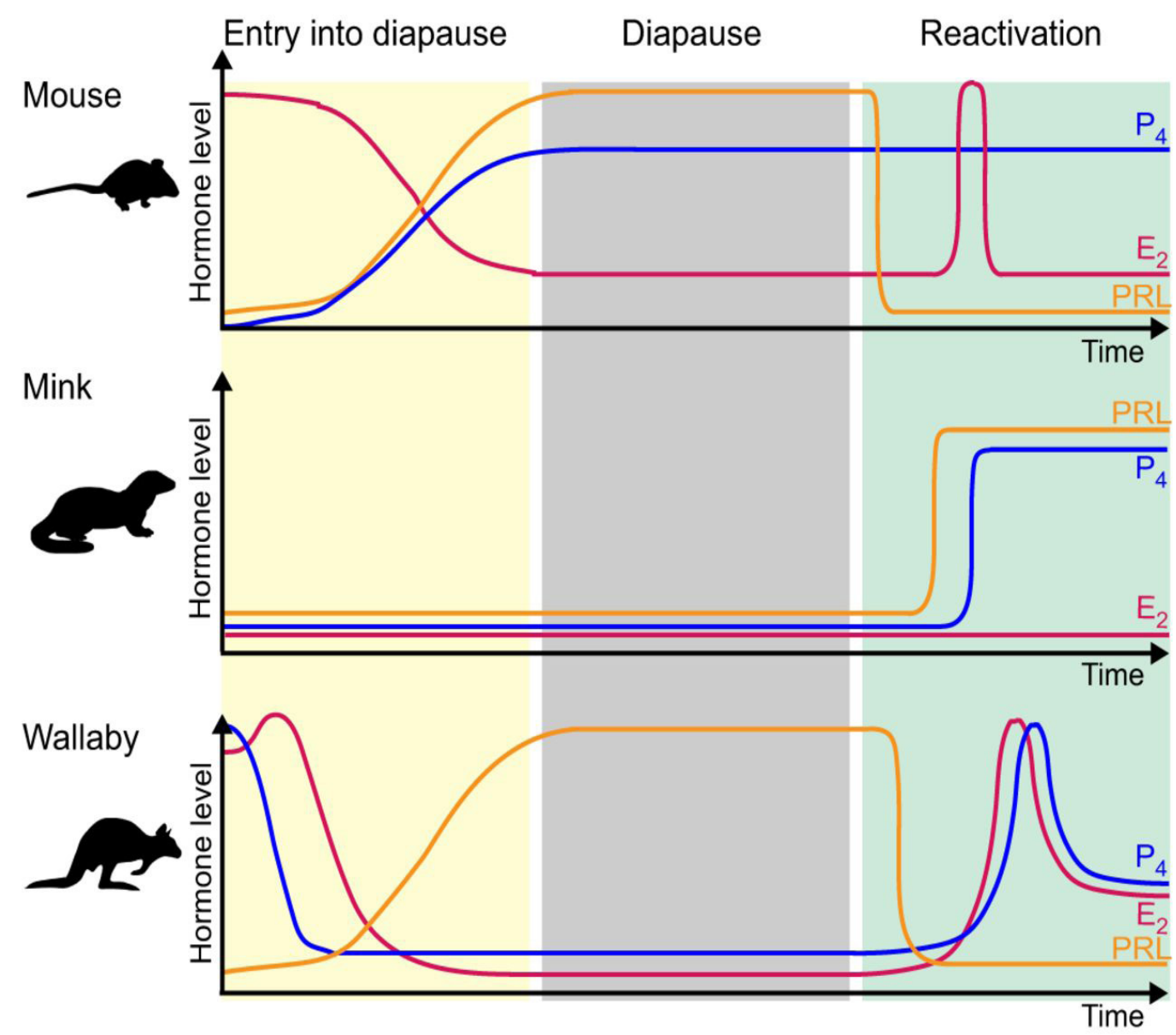

Figure 3. Hormonal changes during embryonic diapause in some species. Progesterone (P4), estradiol (E2), prolactin (PRL) (29).

\section{Cell cycle effect}

Mammalian embryo transforms from zygote to embryo by going through the stages of cell division and differentiation. The main cause of events occurring in diapause is the inhibition of the mitotic cell cycle in embryonic cells, stopping or decreasing cell proliferation. Cells enter a dormant state and apoptosis is prevented by maintaining basal metabolism with protein, RNA synthesis and oxygen consumption (31). Quantification of DNA in mammalian embryos shows that diapause occurs before the $S$ phase of the cell cycle (34), but the absence of 5-bromo-2-deoxyuridine uptake in mink shows that diapause occurs the G0/G1 phase of the cell cycle (3) Immobilized embryonic cells maintain the ability to continue the cell cycle when the diapause ends (31).

\section{Changes in gene expression}

Many known and unknown factors play a role in inducing, maintaining, and ending the diapause. It is still not known how the factors act on the blastocyst at the molecular level, so proteomics and transcriptomic studies continue to eliminate these uncertainties (30). A study in mouse looked at the characterization of blastocysts using microarray technology to identify genes between blastocysts at the diapause stage and blastocysts activated following diapause. In this study, mRNAs were isolated from 100 diapause and activated embryos. 229 different genes have been identified between activated and diapause blastocysts. 229 different genes have been identified between activated and diapause blastocysts. Blastocysts in diapause have 149 genes upregulated compared to active blastocysts and 80 genes that increase in expression level. Genes ranging from diapause and activated blastocysts: genes specifically involved in cell cycle or cell proliferation control; genes involved in energy pathways and carbohydrate mechanisms; genes involved in signalling; genes involved in nuclear transport; genes involved in chromatin remodelling involved in adhesion divided into six functional groups as genes. In accordance with the physiological state of the embryos, an increase was observed in the expression levels of genes that stop cell proliferation at the G0 and G1 stages in the cell (9). In general, the expression of many genes that differ between diapause and activated blastocysts is consistent with the cellular and physiological events that are expected to change with activation. However, none of these 229 genes have been identified as the 'key' to regulate diapause (12). Likewise, 91 genes are upregulated in the mink blastocyst at reactivation from diapause (5). In mink, there was also a clear increase in the amount of polyamines (spermine, spermidine, and putrescine) among the genes upregulated in the activated uterus (17). In recent studies it was found that rapamycin (mTOR) can induce diapause in the mouse blastocyst (1). In a recent study, they identified pathways in gene ontology that are up and down regulated during diapause. What stood out in the study were the genes in lipolysis, glycolysis and pyruvate pathways, and those 
involved in cholesterol metabolism. The results showed that an important metabolic profile characterizes diapause. They also emphasized that mTOR inhibition or failure of mouse embryonic stem cells (mESC) results in a transciptome that summarizes the diapause cellular phenotype (13). There are many factors that are interlinked in this increasingly complex network. Also, there are many factors that have been identified, including microRNAs. Proteomic studies have shown that there are a lot of new effective candidates for diapause (18).

\section{Future directions}

A thorough understanding of how diapause is controlled by molecular aspects has the potential to assist in many situations, enhancing viability of blastocysts in assisted reproductive technologies (ART), generating embryonic stem cells, or identifying new cancer therapies by halting and slowing cell division. It will provide information about the requirements to keep the embryo alive for a long time, thus bringing new approaches to assisted reproductive technologies, helping to improve the embryo culture environment, and be able to introduce approaches that can offer an alternative to cryopreservation. It will also be effective before transfer in determining the selection criteria for the best embryo. Same time it will also be effective before transfer in determining the selection criteria for the best embryo (8). It has a lot of similarities to the invasive nature of cancer cells including embryo reactivation, rapid resumption of cell proliferation and the implantation process (20). Preventing the reactivation of a cancer cell or encouraging it to enter diapause could provide a new treatment method for cancer in the future or prevent metastasis (8). Another important point to be wondered and studied is whether embryonic diapause can occur in other mammalian species, including humans. If embryonic diapause is an evolutionarily conserved phenomenon, it must also be inducible in blastocysts of non-diapause mammals. In the study conducted to prove this hypothesis, blastocysts from domestic sheep were transplanted into mice in which diapause conditions were induced. Sheep blastocysts have been found to stop growing and it has been found to express a gene specific to diapause and to be in diapause. This is shows that embryos from a domestic mammal, the sheep, can enter into diapause when adequate conditions are created (27) (Figure 4). They demonstrated that a non-diapausing species, the sheep, is capable of embryonic diapause, put forward a new hypothesis; could all mammals, including humans, have a common ancestral trait? (26). Understanding the mechanism of embryonic diapause in humans might be a tool for prolonging or enhancement of embryo culture durations in some patients of infertility (32). The study on mTOR has opened the door to new studies on assisted reproductive technologies that can help in many areas such as regenerative medicine, preservation of cell viability after trauma and aging, and stopping mTOR inhibition in cancer cells (1).
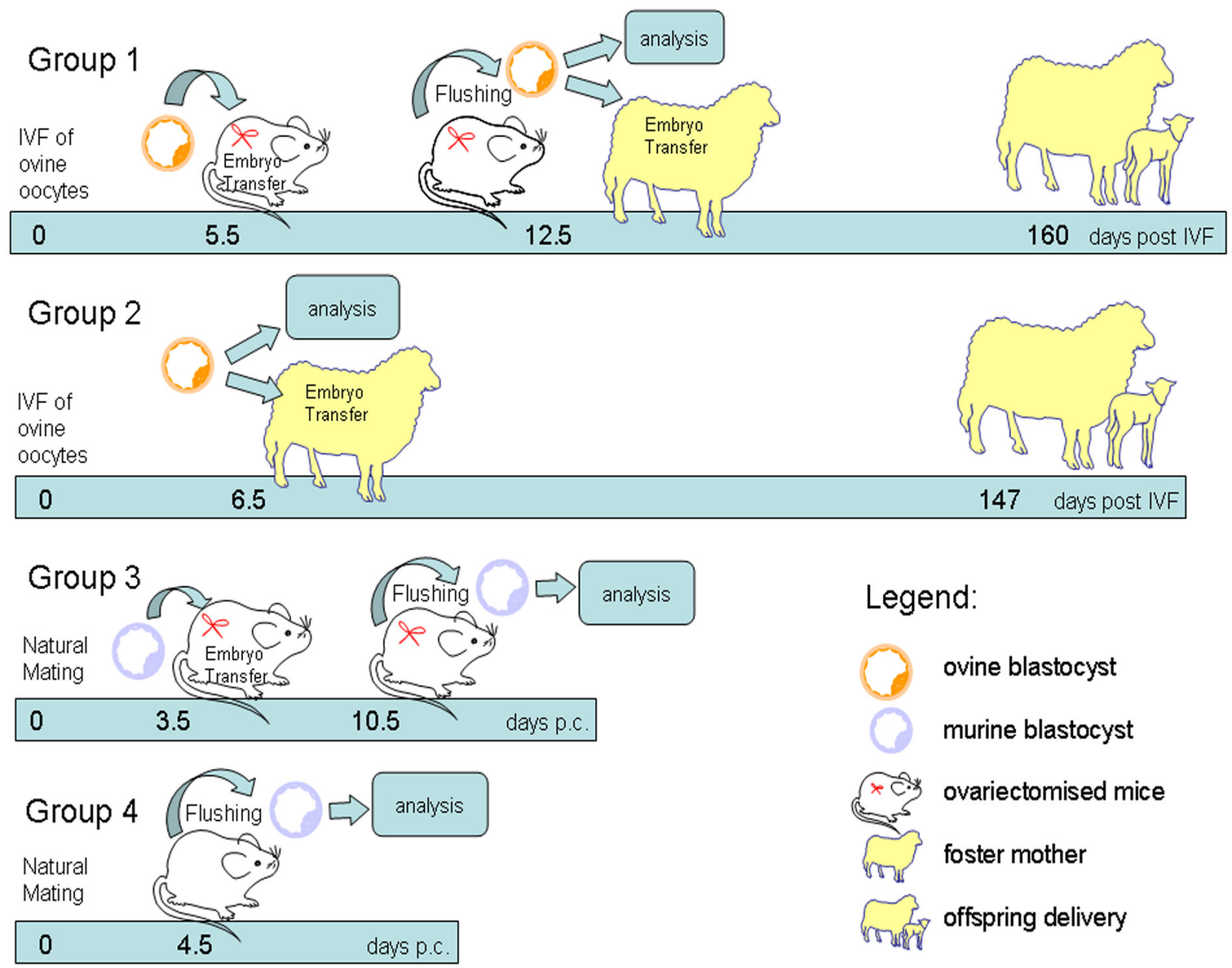

Figure 4. Experimental design of a study of sheep blastocysts in embryonic diapause by transferring ovariectomized pseudo-pregnant mice. Times in the diagram refers to embryos (25). 


\section{CONCLUSION}

Embryonic diapause studies also hold promise for reproductive research. There is a molecular communication between the uterus and blastocyst in the entry and continuation or even the ending of diapause. Understanding all the molecular stages of diapause will not only shed light on evolution, but will also have important contributions in many areas such as assisted reproductive technologies (ART) By determining the molecular level of the mechanism of diapause formation, maintenance and reactivation, it will be understood to what extent it is protected among species and whether all mammalian embryos can enter diapause. New proteomic studies have shown the wealth of new candidates. There are still many unanswered questions on embryonic diapause and many species to work on. Cell and molecular biology techniques, which continues to evolve today, can provide tools to answer all other questions about diapause. Diapause will continue to be a powerful research topic with all its mechanisms.

\section{DECLARATIONS}

\section{Ethics Approval}

Not applicable.

\section{Conflict of Interest}

The authors declare that they have no competing interests.

\section{Author Contribution}

Idea, concept and design: M Çevik, MD Genç

Data collection and analysis: M Çevik, MD Genç

Drafting of the manuscript: M Çevik, MD Genç

Critical review: M Çevik, MD Genç

\section{Data Availability}

The data that support the findings of this study are available from the corresponding author upon reasonable request.

\section{REFERENCES}

1. Bulut-Karslioglu A, Biechele S, Jin H, Macrae TA, Hejna M,Gertsentein M, et al. Inhibition of mTOR induces a paused pluripotent state. Nature. 2016; 540: 119-123.

2. Deng L, Li C, Chen L, Liu Y, Hou R, Zhou X, et al. Research advances on embryonic diapause in mammals. Animal reproduction science. 2018; 198: 1-10.

3. Desmarais JA, Bordignon V, Lopes FL, Smith LC, Murphy BD. The escape of the mink embryo from obligate diapause. Biology of reproduction. 2004; 70 (3): 662-670.

4. Enders AC, Schlafke S, Hubbard NE, Mead RA. Morphological changes in the blastocyst of the western spotted skunk during activation from delayed implantation. Biology of reproduction. 1986; 34(2): 423-437.

5. Fenelon JC, Banerjee A, Lefèvre P, Gration F, Murphy BD. Polyamine-mediated effects of prolactin dictate emergence from mink obligate embryonic diapause. Biology of reproduction. 2016; 95(1): 6-1.

6. Fenelon JC, Lefèvre $\mathrm{P}$, Banerjee A, Murphy BD. Regulation of diapause in carnivore. Reproduction Domestic
Animal. 2016; 51(3): 1-6

7. Fenelon JC, Banerjee A, Murphy BD. Embryonic diapause: development on hold. International Journal of Developmental Biology. 2014; 58(2-3-4): 163-174.

8. Fenelon JC, Renfree MB. The history of the discovery of embryonic diapause in mammals. Biology of reproduction. 2018; 99(1): 242-251.

9. Hamatani T, Daikoku T, Wang H, Matsumoto H, Carter MG, Ko MSH et al. Global gene expression analysis identifies molecular pathways distinguishing blastocyst dormancy and activation. Proceedings of the National Academy of Sciences. 2004; 101(28): 10326-10331.

10. Harper MJK. Sperm and egg transport. Germ cells and fertilization, edn 2, Cambridge University Press, Cambridge. 1982.

11. Harvey MB, Leco KJ, Arcellana-Panlilio MY, Zhang X, Edwards DR, Schultz GA. Endocrinology and paracrinology: Roles of growth factors during peri-implantation development. Human Reproduction. 1995; 10(3): 712-718.

12. Hondo E, Stewart CL. Profiling gene expression in growth-arrested mouse embryos in diapause. Genome biology. 2005; 6(1): 1-4.

13. Hussein AM, Wang Y, Mathieu J, Margaretha L, Song C, Jones DC et al.Metabolic control over mTOR-dependent diapause-like state. Developmental cell. 2020; 52(2): 236-250.

14. Kane MT, Morgan PM, Coonan C. Peptide growth factors and preimplantation development. Human reproduction update. 1997; 3(2): 137-157.

15. Kondoh E, Okamoto T, Higuchi T, Tatsumi K, Baba T, Murphy SK et al.Stress affects uterine receptivity through an ovarian-independent pathway. Human reproduction. 2009; 24(4): 945-953.

16. Leese HJ, Baumann CG, Brison DR, McEvoy TG, Sturmey RG. Metabolism of the viable mammalian embryo: quietness revisited. Molecular human reproduction. 2008; 14(12): 667-672.

17. Lefevre PL, Palin MF, Chen G, Turecki G, Murphy. Polyamines are implicated in the emergence of the embryo from obligate diapause. Endocrinology. 2011; 152(4): 16271639.

18. Liu WM, Pang RT, Cheong AWY, Ng EHY, Kaiqin L, Kai-Fai L et al. Involvement of microRNA lethal-7a in the regulation of embryo implantation in mice. PloS one. 2012: 7(5): e37039.

19. Lopes FL, Desmarais JA, Murphy BD. Embryonic diapause and its regulation. Reproduction. 2004; 128(6): 669678.

20. Massague J, Obenauf AC. Metastatic colonization by circulating tumour cells. Nature. 2016; 529(7586): 298-306. 
21. Mead RA. Delayed implantation in mustelids, with special emphasis on the spotted skunk. Journal of reproduction and fertility. 1981; 29: 11-24.

22. Mead RA. Embryonic diapause in vertebrates. J. Exp. Zool. 1993; 266(6): 629-641.

23. Murphy BD. Progress and challenges in the physiology of reproduction in furbearing carnivores (A review). Norwegian Journal of Agricultural Sciences. 1992.

24. Murphy BD. Embryonic Diapause: Advances in Understanding the Enigma of Seasonal Delayed Implantation. Reproduction in Domestic Animals. 2012; 47: 121-124.

25. Pritchett-Corning KR, Clifford CB, Festing MF. The effects of shipping on early pregnancy in laboratory rats. Birth Defects Research Part B: Developmental and Reproductive Toxicology. 2013; 98(2):, 200-205.

26. Ptak GE, Modlinski JA, Loi P. Embryonic diapause in humans: time to consider?. Reproductive Biology and Endocrinology. 2013; 11(1): 1-4

27. Ptak GE, Tacconi E, Czernik M, Toschi P, Jacek AM, Pasqualino L. Embryonic diapause is conserved across mammals. PloS one. 2012; 7(3): e33027.

28. Renfree MB. Proteins in the uterine secretions of the marsupial Macropusm eugeneii. Developmental biology. 1973; 32(1): 41-49.

29. Renfree MB. Embryonic diapause in marsupials. J Reprod Fertil. 1981; 29: 67-78.

30. Renfree MB, Fenelon JC. The enigma of embryonic diapause. Development. 2017; 144(18): 3199-3210.

31. Renfree MB, Shaw G. Diapause. Annual review of physiology. 2000; 62(1): 353-375.

32. Saadeldin IM. Fertilized embryo diapause, revisited. Journal of Assisted Reproduction and Genetics. 2020; 1-2.

33. Sandell M. The evolution of seasonal delayed implantation. The Quarterly Review of Biology. 1990; 65(1): 23-42.

34. Sherman MI, Barlow PW. Deoxyribonucleic acid content in delayed mouse blastocysts. Reproduction. 1972; 29(1): 123126.

35. Winkle LJ, Tesch JK, Shah A, Campione AL. System $\mathrm{B} 0,+$ amino acid transport regulates the penetration stage of blastocyst implantation with possible long-term developmental consequences through adulthood. Human reproduction update. 2006; 12(2): 145-157.

36. Yoshinaga K, Adams CE. Delayed implantation in the spayed, progesterone treated adult mouse. Reproduction. 1966; 12(3): 593-595.

37. Zhang C, Murphy BD. Progesterone is critical for the development of mouse embryos. Endocrine. 2014; 46(3): 615623. 